\title{
6. Property development, capital growth, and housing affordability in Malaysia
}

Keng-Khoon Ng

Many governments and state agencies in the global South have shifted towards the operation of 'property states' (Haila 201 5 ), 'cities for profits' (Shatkin 2017), or 'neoliberal policies' (Chen and Shin 2019). In Malaysia, retirement and second-home properties have been promoted by the government to lure foreigners to buy relatively cheap freehold properties in cities such as Kuala Lumpur, Penang, Melaka, and Johor Bahru. This development tendency, however, has added pressure to the provision of affordable housing because developers have been more keen to develop international property projects than less profitable products of local housing.

From I 8 March 2020, Malaysia imposed a series of entry and movement restrictions in response to the COVID-I9 pandemic. These restrictions brought uncertainty and new challenges to the (future) operation of international property market. Adopting an urban political economy perspective, this chapter discusses the property-related policy responses taken by Malaysian governments while reflecting on prevailing concerns over housing affordability. Though long-standing impacts on the landscape of housing in Malaysia are hard to predict, the COVID-I9 crisis revealed the inevitable risks of fuelling capital growth through the proliferation of speculative, high-priced international real estate projects with little relevance to society.

Constitutionally, housing development in Malaysia is governed by a series of legal Acts and policies authorised by the Ministry of Housing and Local Government. The federal government's role in housing planning and supply, however, is complemented by the various responsibilities that rest upon state governments and local authorities. While housing is a matter governed by both federal and state governments,

How to cite this book chapter:

$\mathrm{Ng}$, Keng-Khoon. 2022. 'Property development, capital growth, and housing affordability in Malaysia'. In: Shin, Hyun Bang; Mckenzie, Murray; and Oh, Do Young (eds) COVID-I9 in Southeast Asia: Insights for a post-pandemic world. London:

LSE Press, pp. 77-85. DOI: https://doi.org/IO.3 I389/lsepress.cov.f License: CC BY 4.०. 
the latter definitely enjoys more executive power where actual housing development projects are concerned. In short, housing- and land-related development has remained under the state's authority in Malaysia.

Housing development in Malaysia occurs through a dynamic relationship between state and market. Since the r980s, housing had become a private enterprise predominantly undertaken by private developers. For example, the Ninth Malaysia Plan (2006-2010) clearly stated that the 'private sector [acts] as the engine of growth while [the] public sector takes up the roles of facilitator and regulator and civil society and others as partners in development' (Economic Planning Unit 2006). Notwithstanding a small number of houses produced directly by the state, housing has remained a private sector-led activity in Malaysia.

How does the government make sure there is a sufficient housing supply for low-income (defined as below the 4oth percentile of the income distribution) and middle-income (defined as the 40th to 8oth percentiles) households? In practical terms, two basic rules enforced since I982 are worth mentioning: (I) private developers must dedicate at least $30 \%$ of a project's units to low-cost housing, and (2) they must allocate at least $30 \%$ of the units for Bumiputera (i.e. Malay and other indigenous groups of Malaysia) buyers with discounted prices under the Bumiputera Lot Quota Regulation (a pro-Bumiputera affirmative action policy). However, the provision of affordable housing for middle-income households, especially those in urban areas, was not adequately addressed by existing housing policy. In addition, one of the root causes of this housing mismatch issue was the proliferation of international property development.

\section{The proliferation of international property development}

Land has moved to the centre of urban politics in contemporary Malaysia. While land has remained largely a national asset, landbased developments have been pursued aggressively by both federal and state governments as a key fiscal policy to accelerate economic growth. Despite the contributions of international property investment to Malaysia's fairly rapid economic development, it has neither provided improvements towards the democratisation of urban transformation processes nor increased the provision of affordable housing. Undertaking international property development, with speculative, high-growth investment as an inherent feature, has indeed been an exploitation of land. 
The proliferation of international residential property development was bound up with the Malaysia My Second Home programme $\left(\mathrm{MM}_{2} \mathrm{H}\right)$, which provides a special long-term visa (renewable every Io years) for foreigners to reside in Malaysia. This investment migration programme was introduced by the Ministry of Tourism, Arts, and Culture in 2002, with 42,000 participants having been approved as of $202 \mathrm{I}$. To encourage property-buying, for example, $\mathrm{MM}_{2} \mathrm{H}$ participants are allowed to partially withdraw from the required fixed deposit from the second year onwards (50,000 Malaysian ringgit for those aged 50 and above or I 50,000 Malaysian ringgit for those under 50 ) for expenses related to purchasing property. It is important to note that, in 2020 , the federal government lowered the minimum price threshold to avail of this benefit from RMI million to RM600,000 (in the condominium/ apartment segment) in an attempt to solve property overhang. A total of 3 I, 66I unsold residential units were recorded by the end of the first half of 2020 for all of Malaysia; the states of Johor (with 6, I66 unsold units) and Selangor (with 4,865 unsold units) had the most severe property oversupply (NAPIC 2020). To what extent has $\mathrm{MM} 2 \mathrm{H}$ accelerated capital growth in residential property? Could it have actually worsened the problems of property oversupply and housing unaffordability?

Despite the fact that there is no government or market data enabling us to answer these questions, the whole idea of $\mathrm{MM}_{2} \mathrm{H}$ is to capitalise on offshore investments, privileged lifestyles, and the ability to hold long-term visas for small-scale investors. In line with Aihwa Ong's ( I999) concept of 'flexible citizenship', $\mathrm{MM}_{2} \mathrm{H}$ elucidated such intentions by maximising capital accumulation through strategies of migration and border-crossing flexibility. It is interesting to note that, in the first decade of $\mathrm{MM}_{2} \mathrm{H}$ (2002 to 20I2), most of the second-home participants were retirees seeking a high-quality lifestyle with a relatively low cost of living compared to their homelands (see Ono 20I 5; Toyota and Xiang 20I2; Wong and Musa 20I4). In the last decade, however, both local and foreign developers have taken advantage of this policy to scale up lucrative international property projects. As $\mathrm{MM}_{2} \mathrm{H}$ has not been recognised as a discrete housing category, there has not been a distinct type of housing provider or developer for this kind of real estate development. Also, there has not yet been a specific housing policy guide or control the development of $\mathrm{MM}_{2} \mathrm{H}$ projects.

For example, Iskandar Malaysia regularised the formation of an international zone in Iskandar Puteri (formerly known as Nusajaya) to allow more than 25,000 residential units to be built for a speculative 
market of seamless border-crossing living between Singapore and Southern Johor (see $\mathrm{Ng}$ and $\operatorname{Lim} 2017 ; \mathrm{Ng} 2020$ ). The formation and legislation of such an international zone enabled local authorities to charge higher property taxes for foreign homebuyers. Most crucially, all the housing projects located in the international zone were permitted to have $100 \%$ foreign ownership. In other words, there was no requirement to provide the $30 \%$ quota for Bumiputera lots or the $30 \%$ quota for low-income housing in the international zone. It is important to note that the establishment of the international zone thus suspended these two policy requirements that had laid a foundation for housing equality in Malaysia since 1982.

In Iskandar Puteri, a series of exclusive facilities such as international boarding schools, a world-class theme park, a private yacht marina, healthcare centres, and hotels were developed to create a lifestyle matching international standards. Forest City by Country Garden Pacificview is another housing mega-project where a well-capitalised Chinese developer ventured into the emerging market of international property in Johor (see Koh, Zhao, and Shin 202I). This project took its cue from Beijing's promulgation of the Belt and Road Initiative to lure homebuyers from China and the neighbouring regions. These highpriced housing projects, however, did not make any direct contribution to the provision of affordable housing for Malaysians.

To this end, the $\mathrm{MM}_{2} \mathrm{H}$ programme highlights the dynamics of migration policy and economic development under a strong authoritarian state that shaped private housing markets to channel opportunities for land-based developments. In other words, $\mathrm{MM}_{2} \mathrm{H}$ can be best understood as a result of contingent overlaps of the capitalist interests of the state and real estate developers.

The COVID-I9 outbreak in Malaysia caused an unprecedented disruption to the international property market and the operation of the $\mathrm{MM}_{2} \mathrm{H}$ programme. As a result, new applications for $\mathrm{MM}_{2} \mathrm{H}$ were suspended with no clear indication as to when the programme could resume. This sudden decision disrupted international property sales. Furthermore, movement restrictions triggered by the pandemic reshuffled the $\mathrm{MM}_{2} \mathrm{H}$ holders' privileges of border-crossing and visiting their Malaysian homes. For example, the Johor-Singapore border closures had a far-reaching impact on everyday border-crossing practices, not to mention the existing business of international property. Although $\mathrm{MM}_{2} \mathrm{H}$ visa holders could apply for entry permission to return to Malaysia, the government enforced entry restrictions on foreigners who were travelling from countries that had recorded over I 50,000 COVID-I9 
cases. In addition, all passengers travelling into Malaysia were required to serve a two-week quarantine at dedicated quarantine centres.

Several $\mathrm{MM}_{2} \mathrm{H}$ pass holders and consultants reported to local news media their dissatisfaction over a lack of clear directions and considerations given by the Malaysian authorities (see Davison 2020; James 2020; The Star 2020; Thomas 2020). In brief, they wished for $\mathrm{MM}_{2} \mathrm{H}$ visa holders to be treated equally as citizens because they had been contributing a large amount of direct investment to the country's economy. From the perspective of developers, the president of the Real Estate and Housing Developers Association Malaysia opined:

With the Malaysia My Second Home $\left(\mathrm{MM}_{2} \mathrm{H}\right)$ programme put on hold and MCO reinstated, the developers have no other choice but to price the new projects at a very competitive price to survive the pandemic. (Chew and $\operatorname{Lim} 202 \mathrm{I}$ )

To an extent, the statement reflects that property prices could still be adjusted to match the income level of local buyers instead of merely focusing on residential products with higher profit margins.

Taken together, all these perspectives reveal not only the instability of the $\mathrm{MM}_{2} \mathrm{H}$ programme but also the vulnerability of excessive international property projects in the country. For the government, perhaps the time is ripe to think more rigorously about this investment migration program in terms of risk management, investor relations, and inclusiveness. For the real estate developers, the COVID-I9 pandemic exposed underlying concerns over the 'sustainability' of the business model and growth strategies of international property development. What still makes these high-priced residential projects attractive when the selling point of cross-border mobility can no longer be taken for granted? Given that the COVID-I9 pandemic might realistically take several years to bring under control globally, the market response towards international property in the post-coronavirus era remains uncertain. For property investors, the up-and-down market sentiments over high-priced residences should ultimately be seen as a high-risk investment because luxury property supply has simply exceeded market demand in Malaysia.

\section{How helpful has the 2021 national budget been for Malaysians to buy homes?}

Housing affordability is a salient issue in Malaysia, especially for urban dwellers. Between 2002 and 2016, the country's overall housing 
affordability worsened significantly, with Kuala Lumpur, Selangor, and Johor ranked in the 'seriously unaffordable' category (KRI 20I9). Although there were more than 3I,000 unsold units available on the market in 2020 , these units were simply unaffordable for the majority of Malaysians.

How did the government help Malaysians attain homeownership amid the COVID-I9 pandemic? Reintroduced under the Short-Term Economic Recovery Plan by the federal government in June 2020, the Home Ownership Campaign provided a stamp duty exemption on instruments of transfer (for properties below RMI million) and an exemption on instruments for securing loans (for properties between $\mathrm{RM}_{300,000}$ and RM2.5 million), as well as a $10 \%$ price reduction limited to those developers who registered for the scheme. On 6 November 2020 , a series of initiatives targeted at increasing homeownership were announced as part of the 202 I national budget. An extension of the full stamp duty exemption on instruments of transfer and loan agreements was granted for first-time homebuyers buying new-launch or sub-sale properties priced up to $\mathrm{RM}_{5} 00,000$.

How helpful were these stamp duty exemption schemes? Put simply, they only benefited home buyers who managed to secure housing loans from banks. Banks were likely to tighten lending standards because people's debt-servicing capacity was deemed deteriorated due to potential retrenchment and recession, thus making it relatively difficult for people to participate in the schemes and own their first home.

In the $202 \mathrm{I}$ budget, the Ministry of Finance allocated RM500 million to build I 4,000 housing units for those in the bottom $40 \%$ of the income distribution and $\mathrm{RM}_{3}$ I 5 million for the construction of 3,000 housing units by Syarikat Perumahan Negara Berhad, the state-owned, national housing developer, as part of the Rumah Mesra Rakyat programme. The government also offered a rent-to-own scheme for 5,000 PRIMA units limited to first-time home buyers. While Malaysians recognised these positive attempts to build more affordable housing, there was still a lack of immediate action taken by the government to solve pressing housing concerns. For example, governments should expand the rent-to-own scheme by inviting more private developers to join the initiative. In return, the developers could receive special incentives in the form of tax rebates or social responsibility credits. Also, there was the possibility to convert underutilised public buildings or abandoned shopping malls into short-term solutions for the urban poor or the homeless. 
Moreover, there was a worrying tendency for private and government-linked developers alike to focus on the luxury housing market (Lim and Ng 2020). Particularly for the case of Medini Iskandar Malaysia, developers were exempted from building low-cost housing as part of corporate social responsibility requirements. In other cases, developers preferred to pay penalties to local governments instead of meeting their responsibilities. In this regard, local governments should tighten the requirements for private developers to build affordable housing. In short, while Malaysia has actively promoted the $\mathrm{MM}_{2} \mathrm{H}$ programme and the international property market, the government must also put effort into determining the right balance between capital growth and housing affordability.

\section{Conclusions}

Housing development serves Malaysia in two ways. On the one hand, housing provision is premised on increasing home affordability, especially for low- and middle-income groups. On the other hand, the real estate market is an integral part of the government's fiscal policy - which is legislated through an influx of foreign investments and property taxes. In other words, housing production in Malaysia is operated under highly competitive - if not complex - negotiations between a home-owning democracy and a capitalist economy.

Housing has increasingly been regularised into a new geography of profit and politics in Asia (Chen and Shin 2019). To turn property development into a rent-seeking mechanism, the government began to intervene in housing policies and market-oriented practices. Two strategies - control and exploitation - have allowed the government to expand its authority over the public and private realms of property development. These two strategies, however, not only lead to conflicts of interest between the state and non-state actors but they also increasingly collide with social justice and political integrity.

In Malaysia, both COVID-I9 and housing affordability remain huge challenges. On the one hand, the coronavirus crisis exposed new operational issues and policy concerns associated with the $\mathrm{MM}_{2} \mathrm{H}$ programme. On the other hand, the vulnerability of the international property market has been attributed to negative market sentiments arising from movement restrictions. During such challenging times, the government should pay more attention to the local housing supply/demand mismatch and the reordering of state-business relationships in property 
development. International property development is a contested field of capital accumulation built upon market speculation. To avoid irresponsible market speculation, the government should introduce stronger measures to combat housing built for profit, not for living.

\section{References}

Chen, Yi-Ling; and Shin, Hyun Bang (eds). (2019). Neoliberal Urbanism, Contested Cities and Housing in Asia. USA: Palgrave Macmillan.

Chew, Rachel; and Lim, Chelsea J. (202I). 'Impact of MCO 2.0 on the property market'. Edge Property, 22 January. https://perma.cc/DZ8 $5-\mathrm{G}_{4} \mathrm{M}_{3}$ [Last accessed I 8 June 202I].

Davison, Andy. (2020). 'Writing on the wall: Is the $\mathrm{MM}_{2} \mathrm{H}$ programme doomed?' ExpatGo, 29 September. https://perma.cc/V 5 RV-TQBC [Last accessed ro November 2020].

Economic Planning Unit. (2006). The Ninth Malaysia Plan, 2006-2010. Malaysia: Economic Planning Unit. https://perma.cc/XQL2-7GYU [Last accessed 26 May 202I]

Haila, Anne. (2015). Urban Land Rent: Singapore as a Property State. UK: Wiley-Blackwell.

James. (2020). ' $\mathrm{MM} 2 \mathrm{H}$ visa holder stranded abroad and confused'. Free Malaysia Today, 22 May https://perma.cc/8LTW-29NN [Last accessed 26 October 2020].

KRI (Khazanah Research Institute). (2019). Rethinking Housing: Between State, Market and Society. Malaysia: Khazanah Research Institute. https:// perma.cc/N8AD-ANR 7 [Last accessed I4 November 2020].

Koh, Sin Yee; Zhao, Yimin; and Shin, Hyun Bang. (2021). The Micropolitics of Speculative Green Urbanism at Forest City, Iskandar Malaysia. UK: London School of Economics Department of Geography and Environment Discussion Paper Series No. 2I. https://perma.cc/H95 Y-PMXA [Last accessed 26 May 202I].

Lim, Guanie; and Ng, Keng-Khoon. (2020). 'Housing policy in Johor: Trends and prospects', in Francis E. Hutchinson and Serina Rahman (eds) Johor: Abode of Development? Singapore: ISEAS Yusof Ishak Institute, pp. 424-446.

NAPIC (National Property Information Centre). (2020). Residential Unsold Status HI 2020. https://perma.cc/A96R-NZKC [Last accessed to November 2020].

Ng, Keng-Khoon. (2020). 'Johor Bahru's urban transformation: Authority and agency revisited', in Francis E. Hutchinson and Serina Rahman (eds.) 
Johor: Abode of Development? Singapore: ISEAS Yusof Ishak Institute, pp. 407-423.

Ng, Keng-Khoon; and Lim, Guanie. (2017). 'Beneath the veneer: The political economy of housing in Iskandar Malaysia, Johor'. Trends in Southeast Asia, December, Singapore: ISEAS Yusof Ishak Institute.

Ong, Aihwa. (1999). Flexible Citizenship: The Cultural Logics of Transnationality. USA: Duke University Press.

Ono, Mayumi. (2015). 'Commoditization of lifestyle migration: Japanese retirees in Malaysia'. Mobilities, vol. Io, no. 4, pp. 609-627. https://doi.org/ı .I080/I7450IOI.20I4.9I3868

Shatkin, Gavin. (2017). Cities for Profit: The Real Estate Turn in Asia's Urban Politics. USA: Cornell University Press.

The Star. (2020). 'MM2H visa holders hoping for clear directions', 9 June. https://perma.cc/PKX8-JNZM [Last accessed 26 October 2020].

Thomas, Jason. (2020). 'Country's economy, image at stake in $\mathrm{MM}_{2} \mathrm{H}$ freeze, say consultants'. Free Malaysia Today, 7 July. https://perma.cc/3 $\mathrm{P}_{37}$-YGNT [Last accessed ro November 2020].

Toyota, Mika; and Xiang, Biao. (20I2). 'The emerging transnational "retirement industry" in Southeast Asia'. International Journal of Sociology and Social Policy, vol. 32, no. II/I2, pp. 708-7I9. https://doi.org/ıo.ı Iо8 /OI44333I2II 280737

Wong, Kee Mun; and Musa, Ghazali. (20I4). 'Retirement motivation among “Malaysia My Second Home” participants'. Tourism Management, vol. 40, I4I-I 54. https://doi.org/IO.IOI6/j.tourman.20I3.06.002 